\section{New Markets, Diversification, and Regulations for the Telephone Industry}

\author{
Senator John C. Danforth- \\ Chairman, Committee on \\ Commerce, Science, and \\ Transportation, U.S. Senate
}

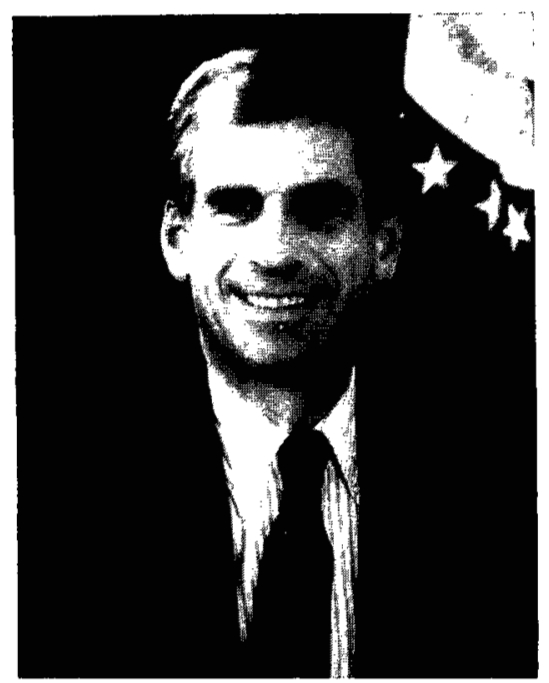

$\mathbf{O}$ ne of the challenges facing the 100th Congress is the shaping of telecommunications policy for the rest of this century and beyond. The new Democratic-led Senate will have before it the question of whether the AT\&T and GTE consent decrees should continue to be administered by a federal district court judge, or placed in the hands of an expert agency such as the Federal Communications Commission. At stake is the future of high quality, reasonably priced, universally available telephone service; the development of new telecommunications services; and the competitiveness of the United States in world markets.

In the 99th Congress, the Senate Commerce Committee undertook the task of thoroughly examining the present status of telecommunications policymaking in the United States and building a record for responsible action. In May, I issued a call for comments from interested parties on whether the restrictions imposed on the Bell Operating Companies by the AT\&T decree should be modified, or whether the forum for administering those restrictions should be shifted from the federal judiciary to the FCC. Soon thereafter, Senate Majority Leader Bob Dole (R-KS) introduced S.2565, the Federal Telecommunications Policy Act of 1986. The purpose of the Dole bill was to provide for exactly the type of change in forum in administering the AT\&T and GTE consent decrees that I had requested comment upon. Therefore, I amended the Committee proceeding to solicit reaction to $\mathrm{S} .2565$ as well. The response was overwhelming. Over 60 sets of comments were filed; most were quite lengthy and detailed.

After careful review of the written record, one conclusion became vividly clear: much is at stake and Congress has a fundamental responsibility to get involved. Senator Dole hit the nail on the head when he said that it was time to put telecommunications policymaking back where it belongs: in the Congress and the Executive branch. However, a straight change-of-forum from federal district court to the FCC misses this goal. While the FCC is clearly a more appropriate forum, Congress must give the FCC guidance on how to administer and amend the decrees.

In August, I set forth a number of proposals to provide this guidance. To obtain further information, I announced two days of Commerce Committee hearings on S.2565 and my amendment proposals.

Many witnesses testified at these hearings, held on September 10 and 16 , and many more submitted testimony for the record. The Committee received the views of the Executive branch, the Bell Operating Companies, AT\&T, the long distance competitors, manufacturers, labor, newspapers, consumers, and others. After reviewing the record of those hearings, I directed the Committee staff to draft a package of amendments to S.2565.

In early October, I introduced this package of amendments. It sets Congressional priorities and gives the FCC specific direction in telecommunications policy. Of first priority is the maintenance of universal and affordable local telephonc service. My amendment package ensures that if the telephone companies are permitted to enter new markets, local ratepayers will not bear the economic burdens of that diversification. Additionally, it requires that competition not be unfairly burdened by telephone company entry into new markets.

Let me describe how the process would work under my amendment package to S.2565. Telephone companies could petition the FCC for waiver, modification, or elimination of the restrictions currently imposed by the AT\&T and GTE decrees. For example, a Bell Operating Company could petition the FCC to provide an information service, to provide interexchange telecommunications service, to manufacture telecommunications equipment, or to provide some service other than local telephone service.

The FCC would be required to grant the petition if it determined that a) the associated economic risks would not be borne by local ratepayers, b) granting the petition would be in the public interest, and c) necessary FCC regulations were in place.

To ensure that any decisions regarding the diversification of telephone companies reflect factors such as the effects on universal and affordable telephone service, competition, and international trade, the FCC would be required to consult with other expert agencies before allowing telephone companies to enter new markets. For example, in determining whether granting a petition would be in the public interest, the FCC would be required to consult with the Attorney General and the Secretary of Commerce regarding the potential effect on competition. The Secretary of Commerce, the United States Trade Representative and other appropriate executive branch agencies would have to be consulted regarding the potential effect on United States trade benefits, competitiveness, and employment. The Secretary of Defense would have to be consulted regarding the potential effect on national security.

The FCC would be required to have regulatory safeguards for ratepayers and competition in place before granting any

Conld. on p. 15 
leadership. It is my hope that the Senate will follow through on the ground breaking work of the Commerce Committee in 99 th Congress and set the course of telecommunications policy for the future. The foundation for responsible action has been laid. The challenge of building upon it remains. current business restrictions. Ratepayers would be protected by a prohibition of direct and indirect cross-subsidization of competitive ventures with ratepayer funds. The FCC would also have to safeguard competition by prohibiting telephone companies from favoring their competitive affiliates over other competitors. To carry out these goals, the FCC would be required to promulgate regulations regarding the transfer of assets between a petitioner and its competitive affiliates at fair market value; the disclosure of network engineering and commercial information; network access and interconnection; accounting and cost allocation; and outside debt financing of competitive businesses.

In the case of a petition to manufacture telecommunications equipment, the FCC would be required to consult with the Attorney General and promulgate regulations that ensure the open and competitive procurement of telecommunications equipment by a telephone company that wanted to purchase equipment from its manufacturing affiliate.

The FCG would also be required to promulgate regulations specifically related to information services and electronic publishing in order to safeguard ratepayers and competition.

The entry of a petitioning telephone company into long distance (interexchange) services would be conditioned upon the completion of equal access obligations. The FCC would be required to promulgate regulations that define and implement equal access. These provisions are designed to impede the ability of a telephone company to favor its own long distance affiliate over other long distance companies in providing needed connections to the local telephone network.

This package of amendments is balanced, fair, and a major advance in the right direction. However, it does not contain all the answers. In particular, I am troubled by leaving competitors with little recourse other than the antitrust laws if competitive abuses do occur. History tells us that antitrust suits take years to reach final resolution and often are too cumbersome to be an effective check on anticompetitive behavior. Congress should attempt to devise a faster, more effective remedy. This might be done by giving the FCC additional authority, by tightening up existing procedures, or some other way.

The changes in the Senate resulting from the recent election place these issues squarely before the new democratic
John C. Danforth was elected United States Senator for Missouri in 1976 . He was elected to a second term in 1982.

Sen. Danforth is Chairman of the Senate Committee on Commerce, Science, and Transportation, a committee with-as its name suggests-wide-ranging jurisdiction. He is the first Missouri Senator to chair a major legislative committee since World War I.

He also serves on the Finance Committe and the Budget Committee. The Finance Committee has jurisdiction over taxation and trade issues; Danforth is Chairman of the panel's International Trade Subcommittee. The Budget Committee sets spending and revenue targets for Senate consideration of the federal budget.

Danforth's election to the U.S. Senate in 1976 was the first victory for a Republican in a Missouri Senate race in 30 years. He won election to a second term in 1982, becoming the only member of his party in the history of Missouri twice elected to serve full terms in the U.S. Senate.

He first ran for public office in 1968 when he was elected Attorney General of Missouri, a campaign that began the resurgence of the Republican Party in Missouri. In 1970, he was the unsuccessful Republican nominee for the U.S. Senate. In 1972, Danforth was re-elected Attorney General.

In 1973 and 197t, he served as Chairman of the Missouri Law Enforcement Assistancc Council, which allocated approximately $\$ 13$ million annually for improvements in Missouri's criminal justice system.

He received his B.A. with honors from Princeton University in 1958. He received a Bachelor of Divinity degree from Yale Divinity School, and a Bachelor of Laws degree from Yale Law School in 1963.

$\because$ Sen. Danforth has received the Presidential World Without Hunger Award, the Outstanding Young Man Award of the Missouri Jaycecs, the Distinguished Service Award of the St. Louis Jaycees, the Distinguished Missourian and Brotherhood Awards of the $\mathrm{Na}$ tional Conference of Christians and Jews, and the Truman Distinguished Lecturer Award of Avila College in Kansas City. He is an honorary member of Alpha Sigma $\mathrm{Nu}$, the National Jesuit Honor Society, and in 1974 was elected to the Missouri Academy of Squires.

He has received an honorary master of arts degree from Yale University and honorary doctoral degrees from Lindenwood College; Lewis and Clark College; Drury College; Rockhurst College; Westminster College: Culver-Stockton College; Maryville College; William Jewell College; Indiana Central University; Southwest Baptist College; and St. Louis University. 